\title{
Evaluation of phytochemical constituents and organoleptic properties of mulberry leaf tea obtained by different processing methods
}

\author{
Young-Hee Jeon, Sang-Won Choi ${ }^{*}$ \\ Department of Food Science and Nutrition, Daegu Catholic University, Gyeongsan 33820, Korea
}

가공방법에 따른 뽕잎차의 기능성성분 및 관능특성 평가

\author{
전영희 · 최상원* \\ 대구가톨릭대학교 식품영양학과
}

\begin{abstract}
This study was conducted to determine the phytochemical constituents and organoleptic properties in mulbeny (Morus alba L.) leaf teas (MLTs) prepared by various processing methods, viz., roasting, steaming, and fermentation. Phytochemical constituents, such as polyphenols, 1-deoxynojirimycin (DNJ), and $z$-aminobutyric acid (GABA), in three different MLTs were quantified by high-performance liquid chromatography. In addition, their organoleptic properties including color, flavor, taste, and overall acceptability were evaluated. Prior to the preparation of MLTs, the three phytochemical constituents of mulberry leaves collected from seven different cultivars and two harvesting seasons were quantified. Of the seven mulbery cultivars examined, Cheongil mulberry leaves harvested in June and September were found to have moderate polyphenol, DNJ, and GABA contents, as compared with the other cultivars. The the roasted mulberry leaf tea (RMLT) was found to have the highest content of total phenolics (2,714.7 $\mathrm{mg} / 100 \mathrm{~g}$ ), while the steamed mulberry leaf tea (SMLT) and fermented mulberry leaf tea (FMLT) had the highest contents of DNJ $(125.6 \mathrm{mg} / 100 \mathrm{~g})$ and GABA $(245.8 \mathrm{mg} / 100 \mathrm{~g})$, respectively. The scores of color, flavor, taste, and overall acceptability of RMLT were significantly higher than those of SMLT and FMLT, which had a peculiar color, flavor, and taste. Thus, each of roasted, steamed and fermented MLTs has characteristic phytochemical constituents and organoleptic property, because of which they need to be further developed each suitable processing method.
\end{abstract}

Key words : mulberry (Morus alba L.) leaf tea, phytochemical constituents, organoleptic property

\section{서 론}

뽕나무는 뽕나무과(Moraceae)의 뽕나무속(Morus)에 속 하는 낙엽 교목 또는 관목식물로서 우리나라를 비롯하여 일본, 중국, 베트남 등 아시아 뿐만 아니라 유럽 및 미국 등에서도 널리 재배되고 있다(1). 전 세계적으로 130여종 품종이 재배되고 있으며, 국내에서는 산상계(Morus

*Corresponding author. E-mail : swchoi@cu.ac.kr Phone : 82-53-850-3525, Fax : 82-53-359-6582

Received 21 September 2018; Revised 12 November 2018; Accepted 13 November 2018.

Copyright (c) The Korean Society of Food Preservation. All rights reserved. bombysis Koidz), 백상계(Morus alba L.) 및 노상계(Morus Lhous Koidsz) 품종이 재배되고 있고, 이들 중 백상계가 주를 이루고 있다(2)

뽕잎은 오랜 전부터 섭취되어 온 것으로「본초강목」에 는 ‘풍을 쫓아주고 폐의 열을 없애주며, 감기로 오는 열, 두통과 기침을 치료해주고 가래를 없애주는' 등 많은 약리 적 효과를 지니고 있다고 기록되어 있다(3).「동의보감」 에는 '따뜻하고 독이 없으며 각기와 수종을 없애주고 대·소 장을 이롭게 하며 하기하고 풍통을 없앤다' 라고 쓰여져 있다(4). 또한, 뽕잎은 고혈압, 동맥경화, 콜레스테롤 및 당 뇨를 다스리는 효능이 있어 예로부터 뽕잎차는 선약(仙藥) 중 제일 귀한 것으로 알려져 있다(4).

뽕잎의 영양성분으로는 단백질, 아미노산, 비타민, 미네 랄 및 다량의 식이섬유소가 함유되어 있으며, 녹차와 비교 
해 볼 때 칼슘은 6 배, 철분은 2 배, 칼륨은 1.4 배, $\mathrm{\gamma}$ -aminobutyric acid(GABA)는 10배 높고, 카페인이 $1 / 600$ 정 도로 미량으로 존재하고 있다 $(5,6)$. 뽕잎의 기능성성분으로 혈 당강하성분인 1-deoxynojirimycin(DNJ)를 비롯하여 신경 안정제 및 혈압강하성분인 $\mathrm{GABA}$ 와 항고혈압, 항당뇨 및 항산화성분의 flavonoid 및 항당뇨, 항비만, 항고지혈증 및 항노화 성분의 stilbenes 및 moracin 유도체가 존재하는 것이 밝혀지면서(7-9) 최근 뽕잎은 건강기능식품 기능성원료로 크게 각광을 받고 있다.

한편, 뽕잎에 함유된 여러 기능성성분의 종류 및 함량은 뽕나무 품종, 재배지역, 수확시기 및 가공방법에 따라 다르 다. Chae 등(10)은 여러 뽕나무 품종 중 YK-209 뽕잎의 기능성성분 함량이 높음을 보고한 바가 있으며, Lee와 Choi(11)는 국상 뽕나무 뽕잎의 폴리페놀화합물의 함량이 다른 품종보다 높음을 보고한 바가 있다. $\operatorname{Kim}(12)$ 및 Zhishen 등(13)은 봄에 수확한 뽕잎의 폴리페놀화합물 함량 이 가을에 수확한 뽕잎보다 높은 것으로 보고한 바가 있었 으나, Lee와 Choi(11)는 가을 초에 수확한 뽕잎의 플라보노 이드 함량이 늦은 봄에 수확한 뽕잎보다 오히려 높다고 다르게 보고하였다. $\operatorname{Lim}$ 등(14)은 볶음처리에 따라 뽕잎의 flavonoid, DNJ 및 GABA 함량이 감소하는 경향을 보고한 바가 있었으며, Lee와 Choi(11)는 뽕잎을 볶을 때 플라보노 이드 성분이 다소 증가하는 것으로 보고한 바가 있다. $\mathrm{Bae}$ 등(15)은 발효처리시 폴리페놀화합물은 크게 감소한다고 보고한 반면, GABA 및 rutin 함량은 발효처리 시간이 길어 짐에 따라 크게 증가함을 보고하였다. 이와 같이 지금까지 품종별, 채취시기 및 가공조건에 따라 뽕잎의 기능성성분 의 함량 변화에 관해 많은 연구가 보고된 바 있으나 고품질 의 뽕잎차 제조에 필요한 가공처리에 따른 뽕잎의 기능성성 분 및 기호도 변화에 관한 보다 상세한 연구는 거의 없는 실정이다.

본 연구는 고품질의 뽕잎차를 개발하기에 앞서 뽕잎용으 로 개발된 7 가지 뽕나무 품종별 및 수확시기별 3 가지 기능 성성분(polyphenol, DNJ 및 GABA) 함량을 측정하였으며, 아울러 현재 뽕잎차용으로 가장 널리 사용되고 있는 청일뽕 을 이용하여 가공방법(볶음, 찜 및 발효)에 따른 뽕잎차의 기능성성분 및 기호도의 변화를 조사한 결과를 보고하고자 한다.

\section{재료 및 방법}

\section{실험재료}

본 실험에서 사용한 7가지 뽕잎용 뽕나무 품종(개량, 검 설, 수계, 신일, 용천, 청일 및 홍올)은 경북 상주 잠사곤충사 업장 유전자원 보존용 시험포장에서 재배한 것을 2016년 6월과 9월에 각각 채취하여 사용하였다. 실험에 사용한 모
든 뽕잎은 수확 후 흐르는 수돗물에 수세한 뒤 탈수 및 음건한 것을 $50 \pm 5^{\circ} \mathrm{C}$ 에서 열풍건조기(JISICO J-300M, Seongdong, Seoul, Korea)에서 건조한(수분 함량 $6.5 \pm 1.2 \%$ ) 후 polyethylene bag에 넣어 밀봉 포장하여 $-30^{\circ} \mathrm{C}$ 에 냉동보 관하면서 기능성성분 분석시료로 사용하였다. 그리고 뽕잎 차(볶음차, 찜차 및 발효차) 제조용 뽕잎은 9월에 수확한 청일 품종을 이용하여 제조하였다.

\section{시 약}

Chlorogenic acid(CGA), rutin(RT), DNJ, phosphoric acid 는 Sigma-Aldrich Chemical Co.(St. Louis, MO, USA)로부터, isoquercitrin(IQT)은 Kanto Chem. Co., Ltd.(Tokyo, Japan)로 부터, quercetin-3- $O$ (6" - $O$-malonyl)- $\beta$-D-glucoside (Q3MG), astragalin(AG), kaempferol 3- $O\left(6^{\prime \prime}\right.$ - $O$-malonyl)- $\beta$-D-glucoside (K3MG)는 Lee와 Choi(11)의 뽕잎으로부터 분리·정제한 것을 사용하였다. 그 외 모든 시약은 HPLC급(Merck, Darmstadt, Germany) 또는 분석용 특급 시약을 사용하였다.

\section{가공방법에 따른 뽕잎차의 제조}

볶음차(roasted tea)는 음건한 뽕잎을 볶음기(Taehwan automation, Bucheon, Korea)에서 볶음 $\left(230 \pm 5^{\circ} \mathrm{C}, 5 \mathrm{~min}\right)$ 과 유념 $(5 \mathrm{~min})$ 과정을 2 회 반복 처리한 뒤 $50 \pm 5^{\circ} \mathrm{C}$ 에서 열풍건 조한 후 방냉하여 볶음차를 제조하였다. 찜차(steamed tea) 는 스텐레스 찜통기(Kitchenart, Incheon, Korea)를 이용하여 끓는 물 위의 찜 틀에 뽕잎을 넣고 5 분간 찜처리한 뒤 음건 및 유념하는 과정을 2 회 반복 처리한 후 위와 같이 열풍건조 한 후 방냉하여 찜차를 제조하였다. 발효차는(fermented tea) 뽕잎을 온도 $40 \pm 5^{\circ} \mathrm{C}$, 습도 $90 \pm 5 \%$ 로 조절된 항온항습기 (TH-ME-065, Jeio Co., Incheon, Korea)에 넣어 24시간 동안 발효시킨 뒤 음건 및 유념 과정을 2회 반복 처리한 후 열풍 건조한 후 방냉하여 발효차를 제조하였다. 제조된 3 가지 뽕잎차(볶음차, 찜차 발효차)는 polyethylene bag에 넣어 밀 봉포장하여 $-30^{\circ} \mathrm{C}$ 에 냉동보관하면서 분석시료로 사용하였 다.

\section{Polyphenol 함량 측정}

항암, 항당뇨 및 항산화성분으로 잘 알려진 polyphenol의 함량은 Lee와 Choi(11)의 방법에 따라 다음과 같이 측정하 였다. 건조 뽕잎 및 뽕잎차 $2 \mathrm{~g}$ 에 $75 \%$ 에탄올수용액 100 $\mathrm{mL}$ 을 가하여 초음파추출기(Power Sonic $420,50 / 60 \mathrm{~Hz}$, $700 \mathrm{~W}$, Hwashintech, Incheon, Korea)에서 1시간씩 2회 추출 한 후 여과(Whatman No.2 filter paper, Whatman International Ltd., Maidstone, England)하여 같은 용매로 $200 \mathrm{~mL}$ 채웠다. 이 중 $20 \mathrm{~mL}$ 을 취하여 $50^{\circ} \mathrm{C}$ 이하에서 감압농축(EYELA, Tokyo Rikakikai Co., Tokyo, Japan)한 후 이것을 같은 추출 용매 $5 \mathrm{~mL}$ 로 용해시켜 상온에 하룻밤 방치시킨 다음 상등 액을 $0.45 \mu \mathrm{m}$ membrane filter(PVDF syringe filter, Finetech 
Research and Innovation Corp., Taichung, Taiwan)로 여과시 킨 후 HPLC를 이용하여 polyphenol 화합물의 함량을 측정 하였으며, 이때 HPLC(Waters e2695 HPLC System, Waters, Millford, MA, USA) 분석조건은 Table 1과 같다. HPLC로 분리된 각 기능성 물질의 peak는 앞서 분리된 표준물질의 retention time과 비교하여 확인하였으며, 표준물질을 이용 하여 작성한 검량곡선으로부터 뽕잎의 품종별, 수확시기별 그리고 가공방법에 따른 뽕잎차의 기능성물질 함량을 계산 하였다.

Table 1. HPLC conditions for analysis of phenolic compounds in mulberry leaf and tea

\begin{tabular}{|c|c|c|c|}
\hline Item & \multicolumn{3}{|c|}{ Operation condition } \\
\hline HPLC system & \multicolumn{3}{|c|}{$\begin{array}{l}\text { Waters e2690/5 HPLC system equipped with } 2998 \\
\text { photodiode array detector and autosampler }\end{array}$} \\
\hline Column & \multicolumn{3}{|c|}{$\begin{array}{c}\text { YMC-Pack Pro } C_{18} \\
(5 \mu \mathrm{m}, 4.6 \times 250 \mathrm{~mm} \text {, YMC Inc., Allentown, PA, USA) }\end{array}$} \\
\hline Flow rate & \multicolumn{3}{|c|}{$0.8 \mathrm{~mL} / \mathrm{min}$} \\
\hline Detector & \multicolumn{3}{|c|}{$\mathrm{UV}_{330,350 \mathrm{~nm}}$} \\
\hline \multirow{9}{*}{$\begin{array}{l}\text { Gradient } \\
\text { elution }\end{array}$} & Time (min) & Acetonitrile & $\begin{array}{l}0.05 \% \mathrm{H}_{3} \mathrm{PO}_{4} \\
\quad \text { in } \mathrm{H}_{2} \mathrm{O}\end{array}$ \\
\hline & 0 & 10 & 90 \\
\hline & 20 & 20 & 80 \\
\hline & 25 & 20 & 80 \\
\hline & 40 & 30 & 70 \\
\hline & 45 & 30 & 70 \\
\hline & 50 & 90 & 10 \\
\hline & 55 & 90 & 10 \\
\hline & 60 & 10 & 90 \\
\hline
\end{tabular}

\section{1-Deoxynojirimycin( $\mathrm{DNJ}$ ) 함량 측정}

누에를 비롯하여 뽕잎, 상백피 등 잠상산물 특유의 항당 뇨성분으로 잘 알려진 $\mathrm{DNJ}$ 의 함량은 9-fluorenylmethyloxycarbonyl chloroformate로 유도체화시킨 후 HPLC를 이용하 여 Choi 등(16)의 방법에 따라 다음과 같이 측정하였다. 즉, 건조 뽕잎 및 뽕잎차 $2 \mathrm{~g}$ 에 $0.05 \mathrm{M} \mathrm{HCl} 100 \mathrm{~mL}$ 을 가하여 초음파추출기에서 1 시간 동안 추출한 후 여과하여 같은 용매로 $100 \mathrm{~mL}$ 채웠다. 이 중 $10 \mathrm{~mL}$ 를 취하여 $50^{\circ} \mathrm{C}$ 이하에 서 감압농축하여 얻은 농축물을 다시 초순수 $2.5 \mathrm{~mL}$ 로 용해 한 후 이 중 $100 \mu \mathrm{L}$ 을 $1.5 \mathrm{~mL}$ Eppendorf tube에 넣고 여기에 $100 \mu \mathrm{L} \quad 0.5 \mathrm{M}$ potassium borate buffer( $\mathrm{pH}$ 9.0)와 $200 \mu \mathrm{L}$ $10 \mathrm{mM} \mathrm{FMOC-Cl}$ 을 넣어 $30^{\circ} \mathrm{C}$ 로 조정된 water bath에서 1시간 동안 반응시킨 후 다시 $100 \mu \mathrm{L} 0.1 \mathrm{M}$ glycine과 100 $\mu \mathrm{L} 1 \%$ acetic acid를 가한 다음 $0.2 \mu \mathrm{m}$ PTFE syringe filter(PALL Life Science, Port Washington, NY, USA)로 여 과하여 HPLC(Waters e2695 HPLC System, Waters) 분석을 실시하였다. $\mathrm{DNJ}$ 함량은 표준물질을 이용하여 작성한 검량
곡선으로부터 계산하였으며, 이때 HPLC 분석조건은 Table 2 와 같다. $\mathrm{HPLC}$ 로 분리된 $\mathrm{DNJ}$ 의 peak는 표준물질 $\mathrm{DNJ}$ 의 retention time과 비교하여 확인하였다. 표준물질을 이용하 여 작성한 검량곡선으로부터 뽕잎의 품종별, 수확시기별 그리고 가공방법에 따른 뽕잎차의 $\mathrm{DNJ}$ 함량을 계산하였다.

\section{${ }^{-A m i n o b u t y r i c ~ a c i d(G A B A) ~ ㅎ ㅏ ㅁ ㄹ ㅑ ㅇ ~ ㅊ ㅡ ㄱ ㅈ ㅓ ㅇ ~}$}

항고혈압, 항당뇨 및 항우울증 성분인 $\mathrm{GABA}$ 함량은 Choi 등(16)의 방법에 따라 아미노산분석기를 이용하여 다 음과 같이 측정하였다. 건조 뽕잎 및 뽕잎차 $5 \mathrm{~g}$ 에 $75 \%$ 에탄올 수용액 $100 \mathrm{~mL}$ 을 가하여 초음파추출기에서 2시간 동안 2회 반복 추출한 후 여과하여 같은 용매로 $200 \mathrm{~mL}$ 채웠다. 이 중 $20 \mathrm{~mL}$ 을 취하여 $50^{\circ} \mathrm{C}$ 이하에서 감압농축 한 후 초순수 $5 \mathrm{~mL}$ 에 용해시켜 냉장고에 하룻밤 방치시킨 후 얻어진 상층액을 membrane filter(PVDF syringe filter, Finetech Research and Innovation Corp.)로 최종 여과한 후 아미노산분석기(L-9880 Amino acid autoanalyzer, Hitachi, Chiyoda, Tokyo, Japan)를 사용하여 GABA 함량을 측정하 였다.

Table 2. HPLC conditions for analysis of DNJ in mulberry leaf and tea

\begin{tabular}{|c|c|c|c|}
\hline Item & \multicolumn{3}{|c|}{ Operation condition } \\
\hline HPLC system & \multicolumn{3}{|c|}{$\begin{array}{l}\text { Waters e2690/5 HPLC system equipped with } 2998 \\
\text { photodiode array detector and autosampler }\end{array}$} \\
\hline Column & \multicolumn{3}{|c|}{ 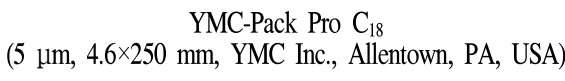 } \\
\hline Flow rate & \multicolumn{3}{|c|}{$1.0 \mathrm{~mL} / \mathrm{min}$} \\
\hline Detector & \multicolumn{3}{|c|}{$\mathrm{UV}_{254 \mathrm{~nm}}$} \\
\hline \multirow{7}{*}{$\begin{array}{l}\text { Gradient } \\
\text { elution }\end{array}$} & Time (min) & $\mathrm{H}_{2} \mathrm{O}$ & $100 \% \mathrm{MeOH}$ \\
\hline & 0 & 45 & 55 \\
\hline & 16 & 45 & 55 \\
\hline & 19 & 10 & 90 \\
\hline & 22 & 10 & 90 \\
\hline & 25 & 45 & 55 \\
\hline & 30 & 45 & 55 \\
\hline
\end{tabular}

관능검사

뽕잎차의 색, 향, 맛 그리고 전반적 기호도에 대한 관능검 사는 대구가톨릭대학교 생명윤리위원회에서 승인을 받아 (승인번호: CUIRB-2016-0140) 식품영양학과 대학생 및 대 학원생 중 15 명을 선발하여 본 연구의 취지와 관련된 교육 을 실시한 후 관능검사를 다음과 같이 실시하였다. 시료는 대조구 및 뽕잎차(볶음차, 찜차 및 발효차) 분말 $1.0 \mathrm{~g}$ 에 $80^{\circ} \mathrm{C}$ 의 증류수 $100 \mathrm{~mL}$ 을 가하여 3 분간 우려낸 후 여과하여 색, 향, 맛 그리고 전반적 기호도에 대해 5점-scale법으로 
관능검사를 실시하였다. 이때, '매우 나쁘다'(1점), ‘나쁘 다'(2점), ‘보통이다'(3점), ‘좋다'(4점), ‘매우 좋다'(5점)으 로 평가하였다.

\section{통계분석}

뽕잎차의 기능성성분의 함량 측정 결과들은 3 회 반복 측정한 후 평균표준편차로 나타내었으며, 각 처리별 평균 치간의 유의성 검정은 SPSS 19.0(Statistical Package for Social Sciences, SPSS Inc., Chicago, IL, USA) software를 이용하여 분산분석을 실시하였다. 평균 간 유의적 차이가 있는 항목에 대해서는 Duncan's multiple range test로 $\mathrm{p}<0.05$ 수준에서 유의차 검증을 실시하였다.

\section{결과 및 고찰}

\section{뽕잎의 품종별 기능성성분의 함량}

뽕잎을 이용한 고품질의 뽕잎차 제조에 앞서 뽕잎용으로 개발된 7가지 뽕나무 품종별 뽕잎의 페놀화합물의 함량을 조사한 결과는 Table 3 과 같다. 먼저 뽕잎의 주된 페놀화합 물인 $\mathrm{CGA}$ 의 경우 6월에 수확한 7가지 뽕나무 품종(개량,
검설, 수계, 신일, 용천, 청일 및 홍올) 중 청일(1,169.3 $\mathrm{mg} / 100 \mathrm{~g}$ ) 품종에서 가장 높은 함량을 나타내었으며, 그 다음으로 개량 $(1,121.6 \mathrm{mg} / 100 \mathrm{~g})>$ 홍올 $(1,085.6 \mathrm{mg} / 100$ $\mathrm{g})>$ 수계 $(712.7 \mathrm{mg} / 100 \mathrm{~g})>$ 검설 $(708.4 \mathrm{mg} / 100 \mathrm{~g})>$ 용천 $(677.6 \mathrm{mg} / 100 \mathrm{~g})>$ 신일 $(626.6 \mathrm{mg} / 100 \mathrm{~g})$ 순으로 낮게 나타 났다. 지금까지 연구보고에 따르면 CGA 성분은 항비만, 항당뇨 및 항고지혈증 생리활성물질로서 보고된 바가 있으 며 $(17,18)$, 아울러 뽕잎 및 커피를 볶을 때 생성되는 색소의 주성분으로 알려져 있다(19). $\mathrm{CGA}$ 를 제외한 5가지 flavonoid(RT, IQT, Q3MG, AG 및 $\mathrm{K} 3 \mathrm{MG})$ 의 함량을 합한 total flavonoid의 함량은 수계 $(1,429.4 \mathrm{mg} / 100 \mathrm{~g})$ 품종에서 가장 높게 나타났으며, 그 다음으로 개량 $(1,260.8 \mathrm{mg} / 100$ $\mathrm{g})>$ 청일 $(1,200.3 \mathrm{mg} / 100 \mathrm{~g})>$ 검설 $(1,130.6 \mathrm{mg} / 100 \mathrm{~g})>$ 홍올 $(891.2 \mathrm{mg} / 100 \mathrm{~g})>$ 신일 $(832.5 \mathrm{mg} / 100 \mathrm{~g})>$ 용천 $(813.1$ $\mathrm{mg} / 100 \mathrm{~g}$ ) 순으로 낮게 나타났다. 품종별 flavonoid 구성성 분 함량의 경우 홍올을 제외한 나머지 품종에서 $\mathrm{Q} 3 \mathrm{MG}$ 성분의 함량이 가장 높았으며, 그 다음으로 rutin 함량이 높았다. 뽕잎의 Q3MG 성분은 항산화, 항당뇨 및 항고지혈 증 성분으로 다른 식물에서 거의 찾아볼 수 없는 뽕잎의 주된 생리적 지표성분이다(20). 그리고 IQT 및 $\mathrm{K} 3 \mathrm{MG}$ 성분 의 함량은 뽕잎 품종에 따라 다소 차이가 있었으며, $\mathrm{AG}$

Table 3. Quantitative changes of polyphenols in mulberry leaves of seven different cultivars by harvest season

\begin{tabular}{|c|c|c|c|c|c|c|c|c|}
\hline \multirow{2}{*}{ Cultivar $^{1)}$} & \multirow{2}{*}{$\begin{array}{l}\text { Harvest season } \\
\quad \text { (month) }\end{array}$} & \multicolumn{7}{|c|}{ Phenolics (mg/100 g, dry weight) ${ }^{2)}$} \\
\hline & & $\mathrm{CGA}^{3)}$ & $\mathrm{RT}^{4)}$ & IQT $^{5)}$ & $\mathrm{Q}^{2} \mathrm{MG}^{6}$ & $\mathrm{AG}^{7}$ & $\mathrm{~K}^{2} \mathrm{MG}^{8)}$ & Total flavonoid \\
\hline \multirow{2}{*}{ GR } & June & $1,121.6$ & 232.5 & 111.0 & 721.2 & $\operatorname{Tr}^{9)}$ & 196.0 & $1,260.8$ \\
\hline & September & $1,261.5$ & 126.7 & 131.0 & 514.7 & 39.4 & 259.1 & $1,070.8$ \\
\hline \multirow{2}{*}{ GS } & June & 708.4 & 255.5 & 110.6 & 614.5 & $\operatorname{Tr}$ & 150.0 & $1,130.6$ \\
\hline & September & 919.7 & 134.8 & 171.0 & 541.2 & 44.4 & 215.7 & $1,107.1$ \\
\hline \multirow{2}{*}{ SG } & June & 712.7 & 335.4 & 144.1 & 817.6 & $\operatorname{Tr}$ & 132.2 & $1,429.4$ \\
\hline & September & $1,024.0$ & 284.3 & 217.0 & 973.3 & 25.0 & 268.8 & $1,768.4$ \\
\hline \multirow{2}{*}{ SI } & June & 626.6 & 146.0 & 87.0 & 523.5 & $\mathrm{Tr}$ & 76.1 & 832.5 \\
\hline & September & 959.8 & 143.6 & 145.0 & 756.1 & $\mathrm{Tr}$ & 263.2 & $1,307.8$ \\
\hline \multirow{2}{*}{ YC } & June & 677.6 & 200.5 & 90.0 & 477.6 & $\mathrm{Tr}$ & 45.0 & 813.1 \\
\hline & September & $1,063.4$ & 154.0 & 130.3 & 550.0 & $\mathrm{Tr}$ & 96.9 & 931.3 \\
\hline \multirow{2}{*}{$\mathrm{CI}$} & June & $1,169.3$ & 231.4 & 97.8 & 704.4 & $\mathrm{Tr}$ & 166.7 & $1,200.3$ \\
\hline & September & $1,045.3$ & 115.4 & 130.2 & 537.2 & 14.6 & 251.6 & $1,049.0$ \\
\hline \multirow{2}{*}{$\mathrm{HO}$} & June & $1,085.6$ & 355.9 & 144.1 & 295.9 & $\mathrm{Tr}$ & 95.3 & 891.2 \\
\hline & September & 920.9 & 211.3 & 204.0 & 342.9 & 67.1 & 171.7 & 997.1 \\
\hline
\end{tabular}

\footnotetext{
${ }^{2)}$ Each value is presented as mean of duplicate determinations.

${ }^{3} \mathrm{CGA}$, chlorogenic acid.

${ }^{4} \mathrm{RT}$, rutin.

${ }^{5} \mathrm{IQT}$, isoquercitrin

${ }^{6}$ Q3MG, quercetin-3- $O\left(6^{\prime \prime}-O\right.$ malonyl)- $\beta-D-$ glucoside.

${ }^{7} \mathrm{AG}$, astragalin.

${ }^{8} \mathrm{~K} 3 \mathrm{MG}$, kaempferol-3- $O_{(}\left(6^{\prime \prime}\right.$ - $O$ malonyl)- $\beta$-D-glucoside

${ }^{9} \mathrm{Tr}$, trace $(<1 \mathrm{mg} / 100 \mathrm{~g})$.
}

${ }^{1)}$ GR, Gaeryang; GS, Geomseol; SG, Sugae; SI, Sinil; YC, Yongcheon; CI, Cheongil; HO, Hongol. 
Table 4. Quantitative changes of DNJ and GABA in mulberry leaves of seven different cultivars by harvest season

\begin{tabular}{cccc}
\hline \multirow{2}{*}{ Cultivar $^{1}{ }^{2}$} & Harvest season & \multicolumn{2}{c}{ Contents $\left(\mathrm{mg} / 100 \mathrm{~g}\right.$, dry weight ${ }^{2)}$} \\
\cline { 3 - 4 } GR & June & 179.3 & GABA \\
\hline \multirow{2}{*}{ GS } & September & 144.6 & 184.9 \\
& June & 108.5 & 82.3 \\
\hline \multirow{2}{*}{ SG } & September & 91.1 & 177.3 \\
& June & 187.2 & 93.9 \\
\hline \multirow{2}{*}{ SI } & September & 141.5 & 161.4 \\
& June & 170.5 & 131.7 \\
\hline \multirow{2}{*}{ YC } & September & 154.3 & 153.6 \\
& June & 142.8 & 121.4 \\
\hline \multirow{2}{*}{ CI } & September & 79.9 & 207.4 \\
& June & 155.2 & 171.9 \\
\hline \multirow{2}{*}{ HO } & September & 84.8 & 183.6 \\
& June & 196.9 & 18.7 \\
\hline
\end{tabular}

${ }^{1)}$ GR, Gaeryang; GS, Geomseol; SG, Sugae; SI, Sinil; YC, Yongcheon; CI, Cheongil; HO, Hongol.

${ }^{2)}$ Each value is presented as mean of duplicate determinations.

성분은 거의 존재하지 않았다. 이와 같이 뽕잎의 페놀화합 물의 함량은 뽕나무 품종에 따라 차이가 있었으며, 그 함량 은 대체로 $1.5-2.8 \mathrm{~g} / 100 \mathrm{~g}$ 범위로 앞서 Lee와 Choi(11)의 보고와 비슷하였다.

한편, 뽕나무 품종별 뽕잎에 존재하는 항당뇨 및 항고혈 압 성분인 $\mathrm{DNJ}$ 및 $\mathrm{GABA}$ 의 함량을 측정한 결과는 Table 4 와 같다. 먼저 품종별 뽕잎의 DNJ 함량은 홍올 품종에서 $196.9 \mathrm{mg} / 100 \mathrm{~g}$ 으로 가장 높았으며, 그 다음으로 수계(187.2 $\mathrm{mg} / 100 \mathrm{~g})>$ 개량 $(179.3 \mathrm{mg} / 100 \mathrm{~g})>$ 신일 $(170.5 \mathrm{mg} / 100$ $\mathrm{g})>$ 청일 $(155.2 \mathrm{mg} / 100 \mathrm{~g})>$ 용천 $(142.8 \mathrm{mg} / 100 \mathrm{~g})>$ 검설 $(108.5 \mathrm{mg} / 100 \mathrm{~g})$ 순으로 낮게 나타났다. 반면, GABA 함량 을 보면 7가지 품종 중 용천의 함량이 $207.4 \mathrm{mg} / 100 \mathrm{~g}$ 으로 가장 높았으며, 그 다음으로 홍올 $(188.0 \mathrm{mg} / 100 \mathrm{~g})>$ 개량 $(184.9 \mathrm{mg} / 100 \mathrm{~g})$ > 청일 $(183.6 \mathrm{mg} / 100 \mathrm{~g})>$ 검설 $(177.3$ $\mathrm{mg} / 100 \mathrm{~g})>$ 수계 $(161.4 \mathrm{mg} / 100 \mathrm{~g})>$ 신일 $(153.6 \mathrm{mg} / 100$ g) 순으로 낮게 나타났다. 지금까지 국내외 연구보고에 의 하면 뽕잎의 DNJ 함량은 $100-480 \mathrm{mg} / 100 \mathrm{~g}$ 범위로 뽕나무 품종에 따라 다소 차이가 있었으며, 특히 개량뽕이 재래뽕 보다 높은 것으로 알려져 있다(21). 그리고 뽕잎의 GABA 함량도 뽕나무 품종에 따라 다소 차이가 있었으며, 대략 $170-260 \mathrm{mg} / 100 \mathrm{~g}$ 함량을 보였는데 이는 녹차보다 약 10 배 높은 것으로 알려져 있다(22). 이와 같이 뽕잎의 3 가지 기능 성성분 함량은 뽕나무 품종별 차이가 있었으며, 어느 한 품종이 전부 다 많이 갖고 있는 것은 없었다(Table 3,4$)$. 따라서 7종의 뽕나무 품종 중 CGA 함량은 청일, 플라보노
이드 함량은 수계, $\mathrm{DNJ}$ 함량은 홍올 그리고 $\mathrm{GABA}$ 함량은 용천이 가장 많이 함유하고 있었으나 현재 오디뿐만 아니라 뽕잎차 및 누에 사육 원료용으로 가장 널리 재배되고 있는 청일 품종은 3 가지 기능성성분을 골고루 많이 함유하고 있음을 알 수 있었다.

\section{뽕잎의 수확시기별 기능성성분의 함량}

수확시기(6월과 9월)에 따른 7가지 뽕나무 품종별 뽕잎 의 페놀화합물의 함량을 조사한 결과는 Table 3 과 같다. 먼저, 페놀화합물 중 $\mathrm{CGA}$ 의 함량은 6 월에 수확한 청일 $(1,169.3 \mathrm{mg} / 100 \mathrm{~g})$ 과 홍올 $(1,085.6 \mathrm{mg} / 100 \mathrm{~g})$ 품종이 9월에 수확한 뽕잎보다 높은 반면, 그 외 5 가지 뽕나무 품종인 개량 $(1,261.5 \mathrm{mg} / 100 \mathrm{~g})$, 검설 $(919.7 \mathrm{mg} / 100 \mathrm{~g})$, 수계 $(1,024.0$ $\mathrm{mg} / 100 \mathrm{~g})$, 신일 $(959.8 \mathrm{mg} / 100 \mathrm{~g})$, 용천 $(1,063.4 \mathrm{mg} / 100 \mathrm{~g})$ 의 경우 9월에 수확한 뽕잎의 함량이 다소 높음을 알 수 있었으 며, 특히 신일과 용천 품종의 $\mathrm{CGA}$ 의 함량은 6 월보다 9 월에 수확한 것이 1.5 배 가량 많이 함유된 것을 확인할 수 있었다. 이러한 결과는 비록 품종은 다르지만 본 연구진들의 선행 연구(16)에서도 확인한 바가 있다. 총 플라보노이드의 함량 은 개량 $(1,260.8 \mathrm{mg} / 100 \mathrm{~g})$, 검설 $(1,130.6 \mathrm{mg} / 100 \mathrm{~g})$, 청일 $(1,200.3 \mathrm{mg} / 100 \mathrm{~g})$ 품종은 6월에 수확한 것이 9월에 수확한 것보다 높은 반면, 수계 $(1,768.4 \mathrm{mg} / 100 \mathrm{~g})$, 신일 $(1,307.8$ $\mathrm{mg} / 100 \mathrm{~g})$, 용천 $(931.3 \mathrm{mg} / 100 \mathrm{~g})$, 홍올 $(997.1 \mathrm{mg} / 100 \mathrm{~g})$ 은 반대로 9월에 수확한 것이 더 높았다. 한편, 뽕잎의 주된 플라보노이드 성분인 $\mathrm{Q} 3 \mathrm{MG}$ 의 함량을 보면 개량(721.2 $\mathrm{mg} / 100 \mathrm{~g})$, 검설 $(614.5 \mathrm{mg} / 100 \mathrm{~g})$, 청일 $(704.4 \mathrm{mg} / 100 \mathrm{~g})$ 은 6월에 수확한 것이, 그 외 수계 $(973.3 \mathrm{mg} / 100 \mathrm{~g})$, 신일(756.1 $\mathrm{mg} / 100 \mathrm{~g})$, 용천 $(550.0 \mathrm{mg} / 100 \mathrm{~g})$, 홍올 $(342.9 \mathrm{mg} / 100 \mathrm{~g})$ 품 종은 9월에 수확한 것이 높은 함량을 보였다. 또한, IQT, $\mathrm{AG}$ 및 $\mathrm{K} 3 \mathrm{MG}$ 의 함량은 모든 품종에서 9월에 수확한 것이 6월보다 높았으며, 특히, IQT 함량은 수계 $(217.0 \mathrm{mg} / 100$ $\mathrm{g}), \mathrm{AG}$ 는 홍올 $(67.1 \mathrm{mg} / 100 \mathrm{~g}), \mathrm{K} 3 \mathrm{MG}$ 는 수계 $(268.8 \mathrm{mg} / 100$ g) 품종이 다른 품종보다 높았다. 반면, RT의 경우 6월보다 9월에 수확한 모든 품종의 뽕잎 함량이 약 1.1-2.0배 낮았으 며, 특히 청일 품종이 2 배 감소하는 경향을 보였다. 이러한 결과를 볼 때 6월에 수확한 뽕잎이 9월에 수확한 뽕잎보다 플라보노이드 함량이 높다는 Lee와 Choi(11)의 결과와 다 소 상이하였는데 이는 뽕나무 부위별 기능성성분의 함량이 품종, 재배지역, 및 수확시기에 따라 달라질 수 있다는 보고 $(2,11)$ 를 뒷받침해 준다.

한편, 뽕잎의 수확시기에 따른 DNJ 및 GABA의 함량을 측정한 결과는 Table 4 와 같다. 먼저, DNJ의 함량을 보면 모든 품종에서 6월에 수확한 뽕잎이 9월에 수확한 뽕잎보 다 높았으며, 특히 홍올 $(196.9 \mathrm{mg} / 100 \mathrm{~g})$, 수계 $(187.2 \mathrm{mg} / 100$ $\mathrm{g})$, 개량 $(179.3 \mathrm{mg} / 100 \mathrm{~g})$, 신일 $(170.5 \mathrm{mg} / 100 \mathrm{~g})$ 의 함량이 청일 $(155.2 \mathrm{mg} / 100 \mathrm{~g})$ 뽕잎보다 높았다. GABA 함량을 보 면, DNJ와 유사하게 6월에 수확한 뽕잎의 함량이 9월에 
수확한 뽕잎보다 높았으며, 특히 용천 $(207.4 \mathrm{mg} / 100 \mathrm{~g})$, 홍 올 $(188.0 \mathrm{mg} / 100 \mathrm{~g})$, 개량 $(184.9 \mathrm{mg} / 100 \mathrm{~g})$ 의 함량이 청일 $(183.6 \mathrm{mg} / 100 \mathrm{~g})$ 뽕잎보다 높은 반면, 검설 $(177.3 \mathrm{mg} / 100$ $\mathrm{g})$, 수계 $(161.4 \mathrm{mg} / 100 \mathrm{~g})$, 신일 $(153.6 \mathrm{mg} / 100 \mathrm{~g})$ 의 함량은 청일 뽕잎보다 낮았다. 이와 같이 $\mathrm{DNJ}$ 와 마찬가지로 $\mathrm{GABA}$ 함량도 수확시기가 빠를수록 함량이 높다는 사실을 확인할 수 있었으며, 이는 Chae 등(10)의 연구에서 수확시 기가 늦어질수록 $\mathrm{DNJ}$ 의 함량이 감소한다는 결과와 일치하 였다. 이러한 결과를 미루어 볼 때, $\mathrm{CGA}$ 함량이 높은 청일 품종, 플라보노이드 함량이 높은 수계 품종, $\mathrm{DNJ}$ 함량이 높은 홍올 품종 그리고 $\mathrm{GABA}$ 함량이 높은 용천 품종을 선별 및 개량하여 비만뿐만 아니라 당뇨 및 고혈압 환자맞 춤형 고품질의 뽕잎차 개발이 필요하다고 제안되어진다. 그러나 아직 이들 품종은 대량 재배가 되고 있지 않는 실정 이기에 본 연구에서는 현재 뽕잎차용 원료로 널리 재배되고 있으며, 다른 뽕나무 품종에 비해 3 가지 기능성 성분의 함량 이 중간수준으로 함유된 청일 뽕잎을 사용하여 볶음, 찜 및 발효처리에 따른 뽕잎차의 기능성 성분 함량 변화를 조사하였다.

\section{가공방법에 따른 뽕잎차의 기능성성분의 함량}

가공방법에 따른 고품질의 뽕잎차를 개발하기 위한 연구 의 일환으로 9월에 수확한 청일 뽕잎을 볶음, 찜 및 발효처 리하여 제조된 뽕잎차의 페놀화합물의 함량을 조사한 결과 는 Table 5와 같다. 먼저 가공처리하지 않은(대조구)의 페놀 화합물의 함량을 측정한 결과, $\operatorname{CGA}(1,045.3 \mathrm{mg} / 100 \mathrm{~g})$, RT(115.4 mg/100 g), IQT(130.2 mg/100 g), Q3MG(537.2 $\mathrm{mg} / 100 \mathrm{~g}), \mathrm{AG}(14.6 \mathrm{mg} / 100 \mathrm{~g}), \mathrm{K} 3 \mathrm{MG}(251.6 \mathrm{mg} / 100 \mathrm{~g})$ 로 각각 나타났다. 볶음차의 경우 $\mathrm{CGA}(1,445.9 \mathrm{mg} / 100 \mathrm{~g})$ 의 함량이 대조구에 비해 유의적으로 높았으며 $(\mathrm{p}<0.05)$, 그 함 량은 약 1.4 배 증가하였다. 그 외 5 가지 플라보노이드의 함량도 각각 RT(144.1 mg/100 g), IQT(168.6 mg/100 g),
Q3MG(561.1 mg/100 g), AG(21.3 mg/100 g), K3MG(254.5 $\mathrm{mg} / 100 \mathrm{~g}$ )으로 대조구에 비해 증가하였다. 찜차의 경우 페 놀화합물은 볶을 때보다 감소하였으며, 특히 CGA(361.6 $\mathrm{mg} / 100 \mathrm{~g}$ )의 함량은 대조구에 비해 유의적으로 낮았으며 $(\mathrm{p}<0.05)$, 그 함량은 약 3 배 감소하였다. 그 외 다른 플라보노 이드의 함량도 각각 $\mathrm{RT}(25.2 \mathrm{mg} / 100 \mathrm{~g}), \mathrm{IQT}(37.2 \mathrm{mg} / 100$ g), Q3MG(99.6 mg/100 g), AG(2.9 mg/100 g) 및 K3MG(41.1 $\mathrm{mg} / 100 \mathrm{~g}$ )으로 대조구에 비해 유의적으로 크게 감소하였다 $(\mathrm{p}<0.05)$. 한편, 발효차 경우 $\mathrm{CGA}(14.5 \mathrm{mg} / 100 \mathrm{~g})$ 함량이 볶음차보다 약 100 배나 낮았으며, 그 외 플라보노이드 성분 도 거의 미량이거나 존재하지 않았다 $(\mathrm{p}<0.05)$. 이와 같이 볶음차의 경우 페놀화합물의 함량이 다소 증가한 반면, 찜 차 및 발효차의 경우 페놀화합물의 함량이 상당히 감소하였 으며, 특히 발효차의 감소 폭이 가장 크게 나타났다. $\mathrm{Lim}$ 등(14)의 연구에 의하면 뽕잎을 $350^{\circ} \mathrm{C}$ 높은 온도로 볶아 유념처리하면 페놀화합물이 크게 감소함을 보고한 바가 있었으나 Lee와 Choi(11)는 $180-220^{\circ} \mathrm{C}$ 에서 볶을 때는 오히 려 증가함을 보고한 바가 있다. 이는 가열처리 시 초기에는 페놀화합물 함량이 증가하였다가 가열온도가 높을수록, 가 열시간이 길어질수록 일부 페놀화합물의 분해로 함량이 감소한다는 보고 $(23,24)$ 를 뒷받침해 준다. 또한, 볶음차의 페놀화합물의 함량이 증가한다는 사실은 비록 원료는 다르 지만 쌀과 같은 곡물 외 포도씨를 가열할 때 총 페놀화합물 이 증가한다는 $\operatorname{Kim}$ 등(25)의 연구결과와 일치하였다. 이러 한 이유로 Lee 등(26)은 볶음처리 과정 중 쌀 내부조직이 파괴되어 페놀화합물이 쉽게 추출되었기 때문이라고 하였 다. 찜차의 페놀화합물의 감소는 높은 온도 및 압력 조건에 서 세포조직의 파괴에 의한 페놀화합물의 유출에 따른 감소 로 여겨지며, 이러한 결과는 스팀처리한 연근에서도 찾아 볼 수 있다(27). 발효차의 페놀화합물의 감소는 갈변을 유도 하는 polyphenol oxidase 활성 증가로 기인된 것으로 녹차를 발효하여 제조한 우롱차, 보이차 및 홍차 순으로 발효가

Table 5. Contents of polyphenols in mulberry leaf teas treated with three different processing methods

\begin{tabular}{|c|c|c|c|c|c|c|c|c|}
\hline \multirow{2}{*}{$\begin{array}{l}\text { Mulberry } \\
\text { leaf tea }\end{array}$} & \multirow{2}{*}{ Significantly ${ }^{1)}$} & \multicolumn{7}{|c|}{ Phenolics (mg/100 g, dry weight) } \\
\hline & & $\mathrm{CGA}^{2)}$ & $\mathrm{RT}^{3)}$ & $\mathrm{IQT}^{4)}$ & $\mathrm{Q} \mathrm{MG}^{5)}$ & $\mathrm{AG}^{\text {() }}$ & $\left.\mathrm{K}^{2} \mathrm{MG}^{7}\right)$ & Total flavonoid \\
\hline Control & ** & $1,045.3 \pm 41.9^{8 / 69)}$ & $115.4 \pm 10.2^{b}$ & $130.2 \pm 12.0^{b}$ & $537.2 \pm 20.9^{\mathrm{a}}$ & $14.6 \pm 0.7^{b}$ & $251.6 \pm 15.9^{\mathrm{a}}$ & $1,049.0 \pm 17.2^{b}$ \\
\hline Roasted tea & ** & $1,445.9 \pm 38.1^{\mathrm{a}}$ & $144.1 \pm 12.0^{\mathrm{a}}$ & $168.6 \pm 13.3^{\mathrm{a}}$ & $561.1 \pm 25.0^{\mathrm{a}}$ & $21.3 \pm 0.5^{\mathrm{a}}$ & $254.5 \pm 16.8^{\mathrm{a}}$ & $1,268.8 \pm 18.2^{\mathrm{a}}$ \\
\hline Steamed tea & ** & $361.6 \pm 25.4^{\mathrm{c}}$ & $25.2 \pm 0.9^{c}$ & $37.2 \pm 1.0^{\mathrm{c}}$ & $99.6 \pm 2.80^{\mathrm{b}}$ & $2.9 \pm 0.0^{\mathrm{c}}$ & $41.1 \pm 1.0^{\mathrm{b}}$ & $208.0 \pm 11.0^{c}$ \\
\hline Fermented tea & ** & $14.5 \pm 0.6^{\mathrm{d}}$ & $\mathrm{ND}^{10)}$ & $12.6 \pm 0.3^{\mathrm{d}}$ & $2.8 \pm 0.0^{\mathrm{c}}$ & ND & ND & $16.5 \pm 0.3^{d}$ \\
\hline
\end{tabular}

\footnotetext{
$1)^{* *}$ Siginificantly different $(\mathrm{p}<0.05)$ among samples in a row.

${ }^{2)} \mathrm{CGA}$, chlorogenic acid.

${ }^{3)} \mathrm{RT}$, rutin.

${ }^{4} \mathrm{IQT}$, isoquercitrin.

${ }^{5} \mathrm{Q}$ MG, quercetin-3- $O$ (6" $-O$ malonyl)- $\beta-D-$ glucoside.

${ }^{6} \mathrm{AG}$, astragalin.

${ }^{7} \mathrm{~K} 3 \mathrm{MG}$, kaempferol-3-O(6" - O-malonyl)-B-D-glucoside.

${ }^{8}$ Each value is presented as mean $\pm \mathrm{SD}(\mathrm{n}=3)$.

${ }_{\text {9)-d }}$ Values in the same column with different superscripts are significantly different $(\mathrm{p}<0.05)$.

${ }^{10} \mathrm{ND}$, not detected.
} 
Table 6. Contents of DNJ and GABA in mulberry leaf teas treated with three different processing methods

\begin{tabular}{ccc}
\hline \multirow{2}{*}{ Mulberry leaf tea } & \multicolumn{2}{c}{ Contents $(\mathrm{mg} / 100 \mathrm{~g}$, dry weight) } \\
\cline { 2 - 3 } & DNJ & GABA \\
\hline Control & $75.7 \pm 5.2^{1 \mathrm{bb} 2)}$ & $118.0 \pm 2.9^{\mathrm{b}}$ \\
Roasted tea & $50.4 \pm 3.3^{\mathrm{c}}$ & $96.5 \pm 2.3^{\mathrm{c}}$ \\
Steamed tea & $125.6 \pm 7.5^{\mathrm{a}}$ & $59.9 \pm 1.4^{\mathrm{d}}$ \\
Fermented tea & $39.5 \pm 2.2^{\mathrm{d}}$ & $245.8 \pm 5.3^{\mathrm{a}}$ \\
\hline
\end{tabular}

${ }^{1)}$ Each value is presented as mean $\pm \mathrm{SD}(\mathrm{n}=3)$.

${ }^{2) a-d}$ Values in the same column with different superscripts are significantly different $(\mathrm{p}<0.05)$.

진행됨에 따라 총 페놀화합물의 함량이 감소하는 보고(28) 와 유사하였다.

한편, 가공방법(볶음, 찜 및 발효처리)을 달리하여 제조 한 뽕잎차의 DNJ 및 GABA 함량을 조사한 결과는 Table 6과 같다. 먼저 DNJ 함량은 찜차의 경우 대조구보다 유의적 으로 높았으며 $(\mathrm{p}<0.05)$, 그 함량은 약 1.7 배 증가한 반면, 볶음차 및 발효차의 경우 대조구보다 약 1.5 배 및 1.9 배 각각 감소하였다. GABA 함량은 발효차의 경우 대조구보다 유의적으로 높았으며( $\mathrm{p}<0.05)$, 그 함량은 2 배 증가한 반면, 볶음차 및 찜차의 경우 다소 크게 감소하였다. 이와 같이 볶음 처리 시 뽕잎차의 $\mathrm{DNJ}$ 함량 감소는 누에분말을 $150^{\circ} \mathrm{C}$ 이상 가열처리 시 $\mathrm{DNJ}$ 함량이 감소한다는 이전 결과와 유사하였으나(29) 찜 처리 시 DNJ 함량 증가는 볶음 처리와 달리 매우 흥미로운 결과를 나타내었다. 그리고 발효에 따 른 GABA 함량 증가는 뽕잎을 혐기적 처리하거나 발효시키 면 증가한다는 Lee(6)의 결과와 유사하였다. 이와 같이 볶음 차의 경우 페놀화합물은 증가한 반면, $\mathrm{GABA}$ 및 $\mathrm{DNJ}$ 는 감소하는 경향을 나타내었다. 찜차의 경우 $\mathrm{DNJ}$ 함량은 증 가한 반면, 페놀화합물 및 GABA 함량은 감소하였다. 발효 차의 경우 $\mathrm{GABA}$ 는 크게 증가한 반면, 페놀화합물 및 $\mathrm{DNJ}$

Table 7. Organoleptic test of mulberry leaf teas treated with three different processing methods

\begin{tabular}{ccccc}
\hline \multirow{2}{*}{ Mulberry leaf tea } & \multicolumn{4}{c}{ Organoleptic test ${ }^{1 \mathrm{~b}}$} \\
\cline { 2 - 5 } & Color & Flavor & Taste & $\begin{array}{c}\text { Overall } \\
\text { acceptability }\end{array}$ \\
\hline Control & $3.7 \pm 0.8^{2 \mathrm{bb3})}$ & $3.5 \pm 1.1^{\mathrm{bc}}$ & $3.4 \pm 1.4^{\mathrm{NS} 4)}$ & $3.3 \pm 0.9^{\mathrm{ab}}$ \\
Steamed tea & $2.9 \pm 0.8^{\mathrm{c}}$ & $2.9 \pm 0.6^{\mathrm{c}}$ & $3.2 \pm 1.2$ & $2.9 \pm 1.2^{\mathrm{b}}$ \\
Roasted tea & $4.3 \pm 0.7^{\mathrm{a}}$ & $4.4 \pm 0.8^{\mathrm{a}}$ & $4.0 \pm 1.1$ & $4.1 \pm 1.2^{\mathrm{a}}$ \\
Fermented tea & $4.2 \pm 0.7^{\mathrm{ab}}$ & $3.9 \pm 0.7^{\mathrm{ab}}$ & $3.6 \pm 1.3$ & $3.4 \pm 1.4^{\mathrm{ab}}$ \\
F-value & $10.860^{* * \star 5)}$ & $8.924^{* * *}$ & 1.094 & $2.555^{*}$ \\
\hline
\end{tabular}

${ }^{13}$ Score scale: 1 , very bad; 2 , bad; 3 , moderate; 4 , good; 5 , very good.

${ }^{2}$ Each value is presented as mean $\pm \mathrm{SD}(\mathrm{n}=3)$.

${ }^{3}$ Values in the same column with different superscripts are significantly different $(\mathrm{p}<0.05)$.

${ }^{4} \mathrm{NS}$, not significant.

${ }^{5)} \mathrm{p}<0.05,{ }^{* * *} \mathrm{p}<0.001$.
는 크게 감소하는 것을 확인할 수 있었다. 이러한 결과를 미루어볼 때, 가공방법을 달리하여 제조한 3가지 뽕잎차(볶 음차, 찜차 및 발효차)는 각각 다른 기능성성분을 많이 함유 하고 있어, 녹차를 이용한 볶음차, 찜차 및 발효차를 개발하 여 이용하고 있듯이 뽕잎차도 각각 별도로 개발할 필요가 있다고 생각된다.

\section{가공방법에 따른 뽕잎차의 기호도}

가공방법을 달리하여 제조한 3가지 뽕잎차(볶음차, 찜차 및 발효차)의 색, 향, 맛 그리고 전반적 기호도를 측정한 결과 Table 7과 같다. 대조구의 경우 침출액의 색, 향, 맛 그리고 전반적 기호도에 대한 평균 점수는 각각 $3.7,3.5$, 3.4, 3.3점으로 나타났다. 찜차의 경우 색(2.9점), 향(2.9점), 맛(3.2점) 및 전반적 기호도(2.9점) 모두 대조구에 비해 낮은 점수를 보였으며, 이는 침출액의 색깔이 클로로필 추출 때 문에 초록색이 진할 뿐만 아니라 뽕잎 특유의 비린내 및 풀냄새 때문인 것으로 사료된다. 발효차의 경우 색(4.2점), 향(3.9점), 맛(3.6점) 및 전반적 기호도(3.4점) 모두 대조구에 비해 높은 점수를 보였으며, 이는 발효과정을 거치면서 뽕 잎의 구수한 맛과 향이 풍부해졌을 뿐만 아니라 뽕잎 특유 의 비린내 및 풀냄새가 감소하였고, 침출액의 색 또한 연한 갈색을 띄고 있어 기호도가 높아진 것으로 생각한다. 볶음 차의 경우 색(4.3점), 향(4.4점) 및 전반적 기호도(4.1점) 모 두 4.0점 이상으로 다른 차에 비해 유의적으로 가장 높은 점수를 나타낸 반면, 맛(4.0점)의 경우 4.0점 이상으로 높은 점수를 나타내었으나 다른 차와 유의적인 차이를 나타내지 않았다. 이와 같이 볶음차가 대조구에 비해 색, 향, 맛 그리 고 전반적 기호도 모두 향상된 것은 볶음차 특유의 고소한 맛과 향 그리고 침출액의 색깔이 갈색을 띄고 있어 소비자 의 기호도가 증가한 것으로 사료된다. Ohmori 등(30)의 연 구에 따르면, 볶음차 제조 시 초기에 찻잎을 덖은 다음 유념 작업을 거치면서 찻잎 조직의 부분적인 파괴로 세포내에 존재하는 휘발성 및 비휘발성 유기산들이 유리되어 chlorophyll을 pheophytin으로 전환시켜 색깔을 황색으로 변하게 함으로써 chlorophyll 함량을 감소시키는 것으로 알 려져 있다. 또한, 볶음 시간이 길어질수록 가열처리에 의해 조직이 파괴되어 chlorophyll 함량은 감소하고, 색이 점차 갈색으로 변하는 것을 확인할 수 있었다. 볶음차의 구수한 향은 현미, 메밀과 같은 곡물이나 둥굴레 등의 뿌리를 볶는 과정에서 생성되는 Maillard 반응생성물인 pyrazine류 화합 물에 의한 것으로 생각된다(31). 이러한 결과를 종합해 보면 가공방법을 달리하여 제조한 3 가지 뽕잎차(볶음차, 찜차 및 발효차)의 기능성성분 분석과 관능검사를 실시한 결과, 각각 독특한 기능성성분을 갖고 있을 뿐만 아니라 특유의 색, 향 그리고 맛을 지니고 있어 녹차의 경우와 같이 볶음차, 찜차 및 발효차 개발이 필요하며, 특히 항비만, 항당뇨 및 항고혈압 생리활성물질로 알려진 flavonoid, DNJ 및 GABA 
를 많이 함유한 개인맞춤형 뽕잎차를 개발하여 판매함으로 써 뽕잎차의 활용도를 크게 향상시킬 필요가 있다고 생각된다.

\section{요 약}

항당뇨, 항고혈압 및 항산화 활성을 갖는 뽕잎을 이용한 고품질의 뽕잎차를 개발하기 위한 연구의 일환으로 먼저 뽕잎차 제조용으로 적합한 뽕잎을 선발하기 위해 7 가지 뽕나무 품종별(개량, 검설, 수계, 신일, 용천, 청일 및 홍올) 및 수확시기별(6월과 9월) 3 가지 기능성성분 즉, 페놀화합 물, $\mathrm{DNJ}$ 및 $\mathrm{GABA}$ 의 함량을 측정하여 뽕잎차용으로 적합 한 청일뽕을 선발하였으며, 나아가 가공방법을 달리하여 제조한 3 가지 뽕잎차(볶음차, 찜차 및 발효차)의 기능성성 분의 함량 및 관능평가 결과는 다음과 같다. 뽕잎의 품종 중 수계는 페놀화합물 $(2,792.4 \mathrm{mg} / 100 \mathrm{~g})$, 홍올은 $\mathrm{DNJ}(196.9 \mathrm{mg} / 100 \mathrm{~g})$ 그리고 용천은 GABA(207.4 mg/100 g) 함량이 각각 가장 높았다. 뽕잎의 수확시기에 따라 페놀 화합물을 정량한 결과, 개량, 검설 및 청일 품종을 제외한 4가지 뽕나무 품종(수계, 신일, 용천 및 홍올)은 9월에 수확 한 뽕잎이 6월에 수확한 뽕잎보다 높은 함량을 나타낸 반면, $\mathrm{DNJ}$ 와 GABA의 경우 6월에 수확한 뽕잎이 9월에 수확한 뽕잎보다 함량이 높았다. 한편, 3 가지 뽕잎차(볶음차, 찜차 및 발효차)의 기능성성분 즉, 페놀화합물, $\mathrm{DNJ}$ 및 $\mathrm{GABA}$ 의 함량을 측정한 결과, 페놀화합물은 볶음차, $\mathrm{DNJ}$ 는 찜차, $\mathrm{GABA}$ 는 발효차에서 유의적으로 가장 높은 함량을 나타내 었다(p<0.05). 한편, 볶음차, 찜차 및 발효차의 색, 향, 맛 그리고 전반적 기호도에 대한 관능평가 결과, 볶음차의 색 (4.3점), 향(4.4점) 및 전반적인 기호도(4.1점)가 찜차 및 발 효차보다 유의적으로 높았으나, 맛(4.0점)의 경우 점수는 높았으나 유의적인 차이를 나타내지 않았다. 발효차 및 찜 차의 경우 볶음차보다 관능평가 점수가 낮았으나 각각 독특 한 맛을 지니고 있었다. 이러한 연구결과를 미루어 볼 때 3 가지 가공방법을 달리하여 제조한 볶음차, 찜차 및 발효뽕 잎차는 각각 특이한 기능성 및 기호성을 갖고 있어 다양한 뽕잎차 개발이 필요하며, 향후 기능성성분을 많이 함유한 뽕잎을 이용한 환자 맞춤형 뽕잎차 개발과 더불어 새로운 고부가가치 기능성소재 및 제품 개발이 기대된다.

\section{감사의 글}

본 연구는 산업통상자원부 지역연고산업육성사업(RIS, R0002111)에 의해 이루어진 것으로 이에 감사드립니다.

\section{References}

1. Song UI (2000) Medicinal plant experiment station of agricultural research center in Gyeongbuk, Korea. In: Illustrated book of medicinal plants, Dongamunhwasa, Seoul, Korea, p 120

2. Lee HW, Sin DH, Lee WJ (1998) Morphological and chemical characteristics of mulberry (Morus) fruit with varietes. Korean J Seric Sci, 40, 1-7

3. Bae KH (2000) The medicinal plants of Korea. Kyo-Hak Pub Co, Seoul, Koera, p 364, 461

4. Hur J (1994) Dongeubogam. Dongeuhak Institute, Ryogang Pub Co, Seoul, Korea, p 2803-2805

5. Lee WC, Kim AJ, Kim SY (2003) The study on the functional materials and effects of mulberry leaf. Food Science and Industry, 36, 2-14

6. Lee SH (2015) Development of mulberry-leaf tea containing $\gamma$ - aminobutyric acid (GABA) by anaerobic treatments. Korean J Food Sci Technol, 47, 652-657

7. Asano N, Oseki K, Tomioka E, Kizu H, Matsui K (1994) $N$-containing sugars from Morus alba and their glycosidase inhibitory activities. Carbohydr Res, 259, 243-255

8. Yang ZZ, Wang YC, Wang Y, Zhang YF (2012) Bioassay-guided screening and isolation of a-glucosidase and tyrosinase inhibitors from leaves of Morus alba. Food Chem, 131, 617-625

9. Chan EWC, Lye PY, Wong SK (2016) Phytochemistry, pharmacology, and clinical trials of Morus alba. Chinese J Nat Med, 14, 17-30

10. Chae JY, Lee JY, Hoang IS, Whangbo D, Choi PW, Lee WC, Kim JW, Kim SY, Choi SW, Rhee SJ (2003) Analysis of functional components of leaves of different mulberry cultivars. J Korean Soc Food Sci Nutr, 32, 15-21

11. Lee WJ, Choi SW (2012) Quantitative changes of polyphenolic compounds in mulberry (Morus alba L.) leaves in relation to varieties, harvest period, and heat processing. Prev Nutr Food Sci, 17, 280-285

12. Kim HB (2005) Anti-oxidative capacity analysis of water-soluble substances according to varieties and maturity stages in mulberry leaves and fruits. Korean J Seric Sci, 47, 62-67

13. Zhishen J, Mengcheng T, Jianming W (1999) The determination of flavonoid contents in mulberry and their scavenging effects on superoxide radicals. Food Chem, 64, 555-559

14. Lim MJ, Bae YI, Jeong CH, Cho BR, Choi JS (2007) Phytochemical components of mulberry leaf tea by different roasting processes. J Agric Life Sci, 41, 17-24 15. Bae HA, Baek H, Park HI, Choung MG, Sohn EH, Kim 
SH, Kim DS, Chung IM, Seong ES, Yu CY, Lim JD (2011) Effect of fermentation time on the chemical composition of mulberry (Morus alba L.) leaf teas. Korean J Medicinal Crop Sci, 19, 276-286

16. Choi SW, Lee YJ, Ha SB, Jeon YH, Lee DH (2015) Evaluation of biological activity and analysis of functional constituents from different parts of mullberry (Morus alba L.) tree. J Korean Soc Food Sci Nutr, 44, 823-831

17. Cho AS, Jeon SM, Kim MJ, Yeo J, Seo KI, Choi MS, Lee MK (2010) Chlorogenic acid exhibits anti-obesity property and improves lipid metabolism in high-fat diet-induced-obese mice. Food Chem Toxicol, 48, 937-943

18. Ong KW, Hsu A, Tan BKH (2013) Anti-diabetic and anti-lipidemic effects of chlorogenic acid are mediated by ampk activation. Biochem Pharmacol, 85, 1341-1351

19. Farah A, de Paulis T, Trugo LC, Martin PR (2005) Effect of roasting on the formation of chlorogenic acid lactones in coffee. J Agric Food Chem, 53, 1505-1513

20. Enkhmaa B, Shiwaku K, Katsube T, Kitajima K, Anuurad E, Yamasaki M, Yamane Y (2005) Mulberry (Morus alba L.) leaves and their major flavonol quercetin 3-(6-malonylglucoside) attenuate atherosclerotic lesion development in LDL receptor-deficient mice. J Nutr, 135, 729-734

21. Kim JW, Kim SU, Lee HS, Kim I, Ahn MY, Ryu KS (2003) Determination of 1-deoxynojirimycin in Morus alba L. leaves by derivatization with 9-fluorenylmethyl chloroformate followed by reversed-phase highperformance liquid chromatography. J Chromatogr A, 1002, 93-99

22. Bang HS, Lee WC (1996) Effect of mulberry leaf sprayed with rutin and GABA on silkworm growth. Korean J Seric Sci, 38, 108-112

23. Hong MJ, Lee GD, Kim HK, Kwon JH (1998) Changes in functional and sensory properties of chicory roots induced by roasting processes. Korean J Food Sci Technol, 30, 413-418

24. Jeong HJ, Kim JS, Sa YJ, Kim MO, Yang J, Kim MJ (2011) Antioxidant activity and a-glucosidase inhibitory effect of jerusalem artichoke (Helianthus tuberosus) methanol extracts by heat treatment conditions. Korean J Medicinal Crop Sci, 19, 257-263

25. Kim SY, Jeong SM, Park WP, Nam KC, Ahn DU, Lee SC (2006) Effect of heating conditions of grape seeds on the antioxidant activity of grape seed extracts. Food Chem, 97, 472-479

26. Lee SH, Lee YR, Hwang IG, Woo KS, Kim KH, Kim KJ, Jeong HS (2009) Antioxidant activities and quality characteristics of germinate rough rice tea according to roasting temperature, time and leaching condition. Korean J Food Sci Technol, 41, 386-391

27. Lee SC, Kim SY, Choi SJ, Lee IS, Jung MY, Yang SM, Chae HJ (2010) Effect of soaking and heat treatment conditions on physicochemical and organoleptic quality of lotus root. Korean J Food Sci Technol, 42, 45-49

28. Jeong CH, Kang ST, Joo OS, Lee SC, Shin YH, Shim KH, Cho SH, Choi SG, Heo HJ (2009) Phenolic content, antioxidant effect and acetylcholinesterase inhibitory activity of Korean commercial green, puer, oolong, and black teas. Korean J Food Preserv, 16, 230-237

29. Ryu KS, Lee HS, Kim KY, Kim MJ, Kang PD (2013) Heat stability and glucose-lowering effect of 1-deoxynojirimycin from silkworm (Bombyx mori) extract powder. Int J Indust Entomol, 27, 277-281

30. Ohmori K, Nakamura S, Watanabe T (1986) Change in color of a tea leaf steamed under different steaming conditions-1) Effect of steaming time. Tea Res J, 63, 24-29

31. Choi SH, Kim KH (1997) Volatile flavor components and formation mechanism of flavor in commercial Polygonatum odoratum tea. J Kor Tea Soc, 3, 141-147 